\title{
Nutritional plans for net energy of growing-finishing swine: economic evaluation
}

\author{
Planos nutricionais de energia líquida para suínos em crescimento e terminação: avaliação \\ econômica \\ Planes de la nutrición de energía neta para cerdos en crecimiento y finalización: evaluación \\ económica
}

\author{
Camilla Mendonça Silva \\ ORCID: https://orcid.org/0000-0001-5259-9316 \\ Universidade Federal de Sergipe, Brasil \\ E-mail: camillamsazoo@gmail.com \\ Charles Kiefer \\ ORCID: https://orcid.org/0000-0001-9622-2844 \\ Universidade Federal de Mato Grosso do Sul, Brasil \\ E-mail: charles.kiefer@ufms.br \\ Ricardo Carneiro Brumatti \\ ORCID: https://orcid.org/0000-0002-4031-320X \\ Universidade Federal de Mato Grosso do Sul, Brasil \\ E-mail: rbrumatti@gmail.com \\ Karina Márcia Ribeiro de Souza Nascimento \\ ORCID: https://orcid.org/0000-0003-0482-0666 \\ Universidade Federal de Mato Grosso do Sul, Brasil \\ E-mail: karina@ufms.br \\ Taynah Vieira Aguiar Farias \\ ORCID: https://orcid.org/0000-0002-4714-2861 \\ Universidade Federal de Mato Grosso do Sul, Brasil \\ E-mail: taynah_vaf@hotmail.com \\ Leticia Emiliani Fantini \\ ORCID: https://orcid.org/0000-0002-3848-9820 \\ Auburn University, United States of America \\ E-mail: lef0022@auburn.edu \\ João Garcia Caramori Júnior \\ ORCID: https://orcid.org/0000-0003-0056-508X \\ Universidade federal de Mato Grosso, Brasil \\ E-mail: caramori@ufmt.br \\ Anderson Corassa \\ ORCID: https://orcid.org/0000-0002-3969-3065 \\ Universidade federal de Mato Grosso, Brasil \\ E-mail: anderson_corassa@ufmt.br
}

\begin{abstract}
The energy content is the most expensive component in the diet for production of swine. In this context, the objective of this study was to evaluate the profitability of nutritional plans with different net energy (NE) levels for barrows and gilts through sensitivity analysis. Nutritional plans with variable levels of NE were evaluated $(2300 ; 2380 ; 2460 ; 2540$; 2620 and $2700 \mathrm{kcal}$ of NE/ $\mathrm{kg}$ ) in diets of 144 swines. The carcasses gross profit was determined based on bonus system (CGPbs) and or based solely on live weights (CGPlw). A sensitivity analysis was performed for each NE nutritional plan with different simulations of price quotes for the ingredients in the diet. The simulations carried out for the price of corn for nutritional plans for barrows, indicate that higher levels of net energy provided the highest CGPbs and CGPlw. For degummed soybean oil, the increase in the concentration of net energy in diets provided an increase of up to $6 \%$ in CGPbs and CGPlw. For gilts, the increase of energy levels in the diets from 2460 to $2700 \mathrm{kcal}$ of net energy improved the gross profit by $17 \%$ when carcasses were sold based on bonus system (CGPbs) and CGPlw was higher when fed with the diet containing $2540 \mathrm{kcal}$ of NE. The increase in the net energy level from 2300 to $2700 \mathrm{kcal}$ in the diet of both barrows and gilts during the growth-finishing phase generated improvements in economic gains, regardless of the way in which the animals are marketed (CGPbs and CGPlw).
\end{abstract}

Keywords: Cost; Energy density; Gilts; Gross profit; Barrow; Bonus system. 


\section{Resumo}

A energia é o componente mais oneroso nas dietas de suínos. Neste contexto, objetivou-se avaliar a rentabilidade dos planos nutricionais com diferentes níveis de energia liquida (EL) para machos castrados e fêmeas suínas por meio de análises de sensibilidade. Foram avaliados planos nutricionais com diferentes níveis de EL (2.300, 2.380, 2.460, 2.540, 2.620 e $2.700 \mathrm{kcal} / \mathrm{kg}$ ) para 144 suínos. O lucro bruto das carcaças foi obtido com base na bonificação de carcaça (LBBon) e ou exclusivamente com base no peso vivo (LBPv). Uma análise de sensibilidade (MOP) foi realizada para cada plano nutricional de EL, com diferentes simulações na cotação dos preços dos ingredientes das dietas. As simulações realizadas para o preço do milho dos planos nutricionais para machos castrados indicam que o aumento de EL proporcionou maior LBBon e LBPv, para o óleo de soja degomado o aumento na EL das dietas proporcionou uma eficiência de lucratividade de até $6 \%$ no LBBon e LBPv em relação ao menor nível de EL. Para fêmeas o aumento de EL de 2.460 para $2.700 \mathrm{kcal}$ melhorou o LBBon em até $17 \%$, o LBPv foi maior em dietas com $2.540 \mathrm{kcal}$ de EL. O aumento no nível de EL para $2.700 \mathrm{kcal}$ na dieta de suínos machos castrados e fêmeas durante a fase de crescimento e terminação melhora a lucratividade, independente da forma de comercialização dos animais.

Palavras-chave: Custos; Densidade energética; Fêmea suína; Lucro bruto; Machos castrados; Sistema de bonificação.

\section{Resumen}

La energía es el componente más caro de las dietas para cerdos. En este contexto, el objetivo fue evaluar la rentabilidad de planes nutricionales con diferentes niveles de energía neta $(\mathrm{EN})$ para machos castrados y hembras porcinas mediante análisis de sensibilidad. Se evaluaron planes nutricionales con diferentes niveles de EN (2300, 2380, 2460, 2540,2620 y $2700 \mathrm{kcal} / \mathrm{kg}$ ) para 144 cerdos. El costo de dietas basadas por el ganacia de peso (CG); ingresos en un sistema de bonificación por canal (IBon) ingresos en remuneración por la venta de animales vivos (IPv); beneficio bruto del sistema de bonificación (LBBon); y beneficio bruto del sistema de venta de animales vivos (LPv) fueron determinados. Se realizó un análisis de sensibilidad (MOP) para cada plan nutricional EN, con diferentes simulaciones en la cotización de los precios de los ingredientes de las dietas. Las simulaciones realizadas para el precio del maíz a partir de los planes nutricionales para machos castrados indican que el aumento en EN proporcionó mayores IBon y LPv, para el aceite de soja desgomado el aumento en el EN de las dietas brindó una eficiencia de rentabilidad de hasta 6\% en IBon y LPv en relación al nivel más bajo de EN. Para las hembras el aumento de EN de 2460 a 2700 kcal mejoró el IBon hasta 17\%, el LPv fue mayor en las dietas con $2540 \mathrm{kcal}$ de EN. El aumento del nivel de EN a $2700 \mathrm{kcal}$ en la dieta de los machos y hembras durante la fase de crecimiento y terminación mejora la rentabilidad, independientemente de la forma de comercialización de los animales.

Palabras clave: Costos; Densidad de energia; Hembra porcina; Beneficio bruto; Machos castrados; Sistema de bonificación.

\section{Introduction}

Feed costs account for about $80 \%$ of the total costs of swine production (Ali et al., 2018). Energy is the most expensive nutritional component (Patience et al., 2015), and the majority of swine diets are composed of high energy feeds. Energy content of the diets directly influence growth performance of the animals (Kil et al., 2013). Swine growth is dependent on the energy concentration of the diets, thus feed intake is adjusted according to the energy levels of the diet (Barbosa et al., 2002; Kil et al., 2013). Therefore, increased energy density in feed may affect weight gain (Wu et al., 2007; Saraiva et al., 2014) and swine feed conversion (Paiano et al., 2008).

Since the energy level of the diet has a significant effect on feed intake, it is desirable that the nutritional requirements be expressed in relation to the energy content of the diet. Rostagno et al. (2017) suggest that the net energy requirements for barrows and gilts in the growth and finishing phase (50-125 kg) are on average 2,560 kcal, while in NRC (2012), the requirements are $2,475 \mathrm{kcal}$ of net energy. However, the literature demonstrates positive effects on the performance of animals with the inclusion of 2,566 kcal (Saraiva et al., 2002) to 2,800 kcal (Gonçalves et al. 2015), which is higher than those recommended by the nutritional requirement tables (NRC, 2012; Rostagno et al., 2017). Although the use of diet with high energy density has a positive effect on feed efficiency (Wu et al., 2007), it is not always economically viable. This is due to feed with high energy value such as corn, oils, and fats having high market values (Mensi et al., 2017). Optimizing energy utilization from adjustments in diet formulation methodology can minimize nutrition costs without compromising animal performance.

It is necessary to know the financial return that the inclusion of a high energy density can generate. In addition, knowledge of nutritional costs can maximize results and basis for decision-making. According to Ali et al. (2018), there is 
sufficient research on the production chain of swine farming; however, there is a lack of in-depth analysis regarding the total feed costs of the production process.

Therefore, this study was carried out with the objective to evaluate the profitability of nutritional plans with different net energy (NE) levels for barrows and gilts from 24 to $100 \mathrm{~kg}$, through sensitivity analysis.

\section{Methodology}

\subsection{Experimental design}

A systematic review was carried out to collect data on swine productive performance, according to the recommendations of Koche (2011) and Roever et al. (2017). The selection of eligible articles adopted exclusion and inclusion criteria, with a search for relevant studies, as well as a critical evaluation of the results, data extraction and synthesis (Leite et al., 2020).

Therefore, economic viability was accessed with performance data (weight gain, feed intake and feed conversion) and carcass composition (Table 1) of the studies with barrows and gilts carried out by Marçal et al. (2018a, b). The quantitative method was adopted in this study (Pereira et al., 2018).

A total of 144 swine were used (Large White/Landrace $\times$ Duroc/Pietrain), 72 barrows and 72 gilts. In both studies the animals were distributed in a randomized complete block design with six levels of net energy in the diet $(2,300,2,380,2,460$, 2,540, 2,620 and 2,700 kcal/kg), using six replicates of two animals each. A basal diet was formulated with 2,300 kcal/kg NE, and then to increase the dietary NE level by $80 \mathrm{kcal} / \mathrm{kg}$ (the difference between each sequential treatment) $10.86 \mathrm{~kg}$ of soybean oil were added, to replace the inert ingredient (kaolin), per ton of diet (Marçal et al., 2018a, b).

Table 1 Dietary net energy (NE) effects on growth performance of barrows and gilts from 24 to $100 \mathrm{~kg}$ body weight (BW)

\begin{tabular}{|c|c|c|c|c|c|c|c|c|c|}
\hline \multicolumn{5}{|c|}{ Net energy (kcal/kg) } & \multicolumn{5}{|c|}{$p$-value } \\
\hline & 2,300 & 2,380 & 2,460 & 2,540 & 2,620 & 2,700 & SEM & Linear & Quadratic \\
\hline \multicolumn{10}{|c|}{ Barrows* } \\
\hline IW & 25.05 & 25.18 & 25.68 & 25.07 & 25.05 & 25.1 & - & - & - \\
\hline FW & 101.53 & 103.03 & 102.75 & 102.72 & 103.92 & 106.3 & 1.203 & 0.011 & 0.345 \\
\hline DWG & 1.02 & 1.04 & 1.03 & 1.04 & 1.05 & 1.08 & 0.015 & 0.007 & 0.224 \\
\hline DFI & 2.65 & 2.6 & 2.43 & 2.43 & 2.41 & 2.37 & 0.061 & $<0.001$ & 0.273 \\
\hline $\mathrm{FC}$ & 2.6 & 2.5 & 2.36 & 2.34 & 2.3 & 2.19 & 0.064 & $<0.001$ & 0.667 \\
\hline $\mathrm{BF}$ & 13.24 & 13.11 & 13.21 & 13.44 & 15.51 & 15.89 & 0.953 & 0.012 & 0.292 \\
\hline LD & 21.11 & 20.25 & 19.04 & 19.15 & 18.6 & 17.75 & 0.001 & $<0.001$ & 0.843 \\
\hline LMA & 48.83 & 48.48 & 49.33 & 50.34 & 50.04 & 49.96 & 1.025 & 0.242 & 0.868 \\
\hline Learn & 37.92 & 38.53 & 38.53 & 36.78 & 39.52 & 38.31 & 1.086 & 0.706 & 0.750 \\
\hline \multicolumn{10}{|c|}{ Gilts** } \\
\hline IW & 23.12 & 23.32 & 23.27 & 23.22 & 23.27 & 23.27 & - & - & - \\
\hline FW & 99.68 & 99.72 & 102.89 & 102.27 & 100.22 & 102.92 & 3.13 & 0.498 & 0.785 \\
\hline DWG & 0.85 & 0.85 & 0.89 & 0.88 & 0.85 & 0.89 & 0.029 & 0.494 & 0.788 \\
\hline DFI & 2.32 & 2.17 & 2.27 & 2.11 & 2.07 & 2.07 & 0.082 & 0.018 & 0.812 \\
\hline $\mathrm{FC}$ & 2.73 & 2.55 & 2.55 & 2.4 & 2.44 & 2.33 & 0.107 & $<0.001$ & 0.494 \\
\hline $\mathrm{BF}$ & 9.89 & 8.66 & 9.01 & 10.34 & 9.64 & 11.28 & 0.839 & 0.088 & 0.188 \\
\hline LD & 47.23 & 45.00 & 44.68 & 46.23 & 43.47 & 46.09 & 1.126 & 0.354 & 0.149 \\
\hline LMA & 38.62 & 36.61 & 36.67 & 37.82 & 36.38 & 37.25 & 1.244 & 0.499 & 0.453 \\
\hline Learn & 58.98 & 59.48 & 59.24 & 58.63 & 58.75 & 58.06 & 0.464 & 0.041 & 0.283 \\
\hline
\end{tabular}

IW = initial weight (kg); FW = final weight (kg); DWG = daily weight gain (kg); DFI = daily feed intake (kg/day); FC = feed conversion; BF $=$ backfat $(\mathrm{mm}) ; \mathrm{LD}=$ loin depth $(\mathrm{mm}) ; \mathrm{LMA}=$ loin muscle area $\left(\mathrm{cm}^{2}\right) . \mathrm{SEM}=$ standard error of the mean. *Adapted from Marçal et al. (2018a); **Adapted from Marçal et al. (2018b).

Source: Authors.

At the start of this 75-day experiment, mean initial weight of the animals was $24.22 \pm 1.03 \mathrm{~kg}$. For the nutritional plans evaluation, the experiment was divided into three phases: $24-50 \mathrm{~kg}, 50-70 \mathrm{~kg}$, and 70-100 kg (Marçal et al., 2018a, b), however for the economic analysis the whole period was used (24 to $100 \mathrm{~kg}$ ). Experimental diets were formulated according to the 
recommendations of the Brazilian Tables for Poultry and Swine for barrows and gilts of high genetic potential and average performance (Rostagno et al., 2011).

\subsection{Economic equations}

Based on the data obtained in Marçal et al. (2018a,b) research, the average values of nutrient inputs, and price paid in live swine during the corresponding period between 2014 and 2015 (CEPEA, 2017) the corresponding metrics were calculated: feed cost of weight gain (FCwg - US\$/kg of weight gain); revenue into carcass bonus system (RCbs - US\$/animal); (Bonus system is when farmers get an extra payment per swine with high percentage of lean meat); revenue for the commercialization of animals by live weight (RLws - US\$/animal); gross profit when carcasses were sold based bonus system (CGPbs) and gross profit when sold based solely on live weight (CGPlw).

Feed cost of weight gain (FCwg) of each treatment was determined based on the price of the ingredients in the diets, on growth performance data weight gain (WG) and feed conversion (FC), adopting the following equation:

$$
F C w g=(W G * F C) *(U S \$ / k g \text { diet })
$$

To obtain revenue into carcass bonus system (RCbs US\$/animal) the equation proposed by Guidoni (2000) was used:

$$
R C b=U S \$ / k g L W *((H C W / \% C Y) *(23.6+0.286 * H W C+\% L W))
$$

Where: US\$ $/ \mathrm{kg} \mathrm{LW}=$ price paid to the producer per kilogram of live swine; $\mathrm{HCW}=$ hot carcass weight; $\% \mathrm{CY}=$ percentage of carcass yield and $\% \mathrm{LW}=$ percentage of lean meat in the carcass. Being that, the carcass yield was estimated at $75.21 \%$ of slaughter weight.

In order to obtain the revenue for the commercialization of animals by live weight (RLws US\$/animal) the following equation was used:

$$
R L w=F W * U S \$ / k g L W
$$

Where: $\mathrm{FW}=$ final weight of animals at slaughter; US\$/kg LW= price paid to the producer per kilogram of live swine.

The difference between the gross revenue of each commercialization system of animals and the costs resulted in the gross profit of each system (CGPbs and CGPlw US\$/animal), was calculated by the equation:

$$
G P=G R-F C w g
$$

Where: GP= gross profit of each system (CGPbs and CGPlw US\$/animal); GR= gross revenue of each system (RCbs and RLws); FCwg= feed cost of weight gain.

\subsection{Methodology for economic analysis of the MPO scenarios}

After the determination of the results of equations, a sensitivity analysis was made for each level of net energy, adopting the MPO methodology (Weston and Brigham 2000), presupposing the construction of three economic scenarios: more probable $(\mathrm{M})$; optimistic $(\mathrm{O})$; pessimistic $(\mathrm{P})$. These scenarios were designed according to the price simulations per kilogram of corn, soybean meal, degummed soybean oil and for the price of live swine (CEPEA, 2017). Where the prices of the other ingredients 
used in the analyzed diets did not vary according to the simulations carried out.

The more probable scenario (M) reflects the default scenario of the price quote of inputs during the biennium 2014/2015 (CEPEA, 2017). The pessimistic scenario (P) was obtained by calculating the positive standard deviation of the mean prices for the period 2014/2015 (CEPEA, 2017). For the optimistic scenario (O), the calculation of the negative standard deviation of the mean prices for the period was applied.

For the most probable scenario the price quote of US\$ $0.17 / \mathrm{kg}$ of corn used in diets was adopted, and in the optimistic and pessimistic scenario the quote for these ingredients varied by $12.77 \%$. For degummed soybean oil the quote adopted in the most probable scenario was of US $\$ 0.75 / \mathrm{kg}$, whereas in the optimistic and pessimistic scenario the price quote varied $10.36 \%$. While in the most probable scenario for soybean meal, the quote adopted was US $\$ 0.36 / \mathrm{kg}$, with variation of $8.65 \%$ in the optimistic and pessimistic scenario. Lastly, for the price paid per kilogram of swine, the value of US $\$ 1.38 / \mathrm{kg}$, in most probable scenario, varying $14 \%$ in the optimistic and pessimistic scenario.

\section{Results and Discussion}

In the sensitivity analysis for the simulations carried out for the price of corn in the nutritional plans for barrows, the highest level of net energy provided the highest CGPbs and CGPlw. Thus, it is possible to verify diets in which 2,700 kcal of NE were used provided an efficiency in profitability of $4.27 \%$ on the bonus system (CGPbs), and of $4.84 \%$ in the system of revenue for live weight (CGPlw) compared to the baseline level of NE in the optimistic scenario (Figure 1).

However, the simulations carried out for a variation of degummed soybean oil (Figure 1), showed that the increase in the concentration of NE in diets provided a profitability efficiency of up to 6\% in CGPbs and CGPlw, in relation to the lower level of net energy (2,300 kcal of NE). Whereas, in the simulations carried out from the price variation of soybean meal, it can be seen in the optimistic scenario that the increase in the energy density from 2,300 kcal of NE to 2,700 kcal generated an increase of $4.45 \%$ in CGPbs and $5.02 \%$ in CGPlw.

Figure 1 Gross profit when carcasses were sold based on bonus system (CGPbs) and gross profit when sold based solely on live weight (CGPLw) from the analysis, scenarios more probable $(\mathrm{M})$, optimistic $(\mathrm{O})$ and pessimistic $(\mathrm{P})$, on the price of corn, degummed soybean oil and soybean meal, applied in nutritional plans of net energy for barrows.

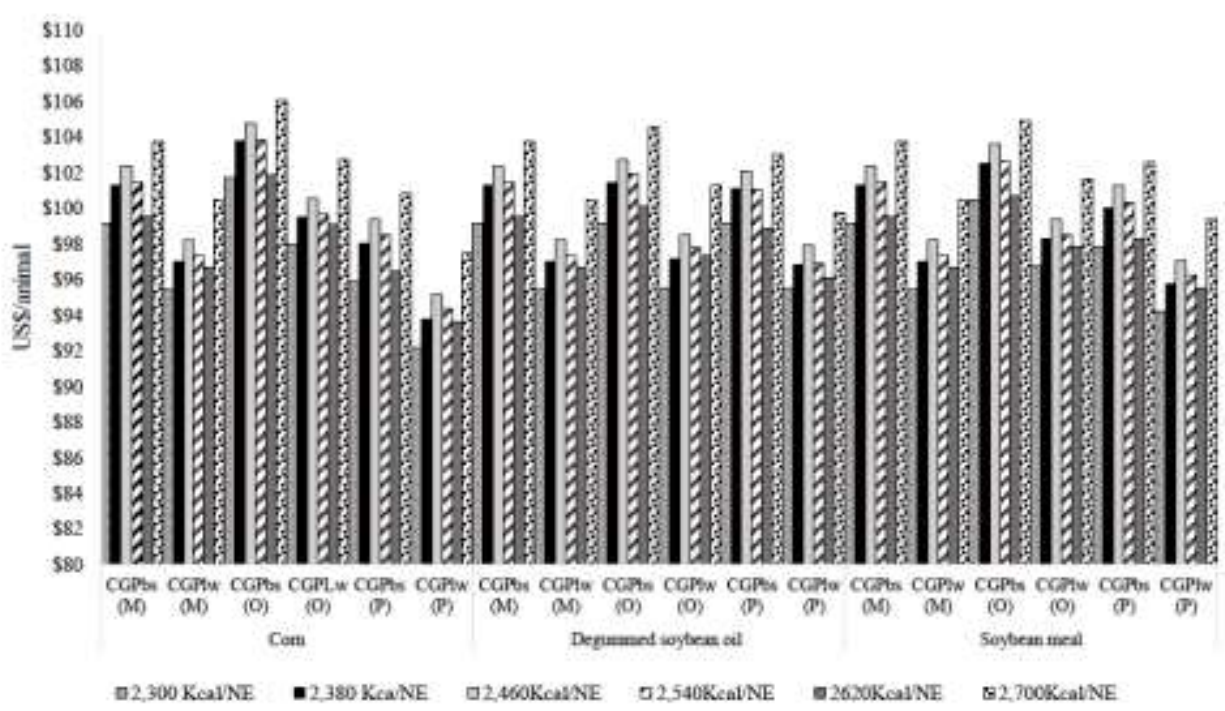

Source: Authors. 
In general, the results of the economic study for barrows in the simulations performed for corn, degummed soybean oil and soybean meal showed that the increase in the NE level in the diets increased the profitability, independent of the carcass sales system, bonus system or live weight payment. This can be justified by the high revenue generated (RCbs and RLws), which was higher with the inclusion of the maximum level of $\mathrm{NE}(2,700 \mathrm{kcal} / \mathrm{kg})$, thus compensating the feed cost of the weight gain, which was higher in comparison to the others energy levels (Table 2). It is still possible to verify from the magnitude of the performance results (Table 1) that higher profitability reflected the results of weight gain and feed consumption (Marçal et al., 2018b).

Table 2 Revenue and feed cost of weight gain of the plans net energy sequences for barrows and gilts generated from variation in the price quote of corn, degummed soybean oil and soybean meal and price paid per kilogram of swine in the optimistic scenario

\begin{tabular}{|c|c|c|c|c|c|c|c|}
\hline & \multicolumn{7}{|c|}{ Net energy $(\mathrm{kcal} / \mathrm{kg})$} \\
\hline & & 2,300 & 2,380 & 2,460 & 2,540 & 2,620 & 2,700 \\
\hline & \multicolumn{7}{|c|}{ Barrows } \\
\hline \multirow[t]{3}{*}{$1 *$} & RCbs & 143.10 & 145.75 & 145.29 & 145.19 & 145.49 & 149.25 \\
\hline & RLws & 139.43 & 141.48 & 141.10 & 141.06 & 142.71 & 145.98 \\
\hline & FCwg & 41.40 & 41.94 & 40.53 & 41.39 & 43.62 & 43.21 \\
\hline \multirow[t]{3}{*}{$2 *$} & $\mathrm{RCbs}$ & 143.10 & 145.75 & 145.29 & 145.19 & 145.49 & 149.25 \\
\hline & RLws & 139.43 & 141.48 & 141.10 & 141.06 & 142.71 & 145.98 \\
\hline & FCwg & 43.96 & 44.28 & 42.58 & 43.25 & 45.37 & 44.74 \\
\hline \multirow[t]{3}{*}{$3 *$} & $\mathrm{RCbs}$ & 143.10 & 145.75 & 145.29 & 145.19 & 145.49 & 149.25 \\
\hline & RLws & 139.43 & 141.48 & 141.10 & 141.06 & 142.71 & 145.98 \\
\hline & FCwg & 42.67 & 43.19 & 41.72 & 42.55 & 44.82 & 44.36 \\
\hline \multirow[t]{4}{*}{$4^{*}$} & RCbs & 163.78 & 164.09 & 158.95 & 167.62 & 166.56 & 175.26 \\
\hline & RLws & 155.57 & 155.63 & 160.58 & 159.61 & 156.41 & 160.62 \\
\hline & FCwg & 46.69 & 45.03 & 49.63 & 46.67 & 47.13 & 48.41 \\
\hline & \multicolumn{7}{|c|}{ Gilts } \\
\hline \multirow[t]{3}{*}{$1 *$} & RCbs & 144.11 & 144.39 & 139.86 & 147.49 & 146.55 & 154.22 \\
\hline & RLws & 136.88 & 136.94 & 141.29 & 140.44 & 137.63 & 141.33 \\
\hline & FCwg & 43.45 & 42.00 & 46.38 & 43.72 & 44.23 & 45.51 \\
\hline \multirow[t]{3}{*}{$2 *$} & RCbs & 144.11 & 144.39 & 139.86 & 147.49 & 146.55 & 154.22 \\
\hline & RLws & 136.88 & 136.94 & 141.29 & 140.44 & 137.63 & 141.33 \\
\hline & FCwg & 46.69 & 44.86 & 49.27 & 46.18 & 46.49 & 47.61 \\
\hline \multirow[t]{3}{*}{$3 *$} & RCbs & 144.11 & 144.39 & 139.86 & 147.49 & 146.55 & 154.22 \\
\hline & RLws & 136.88 & 136.94 & 141.29 & 140.44 & 137.63 & 141.33 \\
\hline & FCwg & 45.33 & 43.75 & 48.28 & 45.43 & 45.91 & 47.19 \\
\hline \multirow[t]{3}{*}{$4 *$} & $\mathrm{RCbs}$ & 163.78 & 164.09 & 158.95 & 167.62 & 166.56 & 175.26 \\
\hline & RLws & 155.57 & 155.63 & 160.58 & 159.61 & 156.41 & 160.62 \\
\hline & FCwg & 46.69 & 45.03 & 49.63 & 46.67 & 47.13 & 48.41 \\
\hline
\end{tabular}


Figure 2 Gross profit when carcasses were sold based on bonus system (CGPbs) and gross profit when sold based solely on live weight (CGPlw) from the analysis scenarios, more probable (M), optimistic (O) and pessimistic (P), on the price of corn, degummed soybean oil and soybean meal, applied in nutritional plans of net energy for gilts.

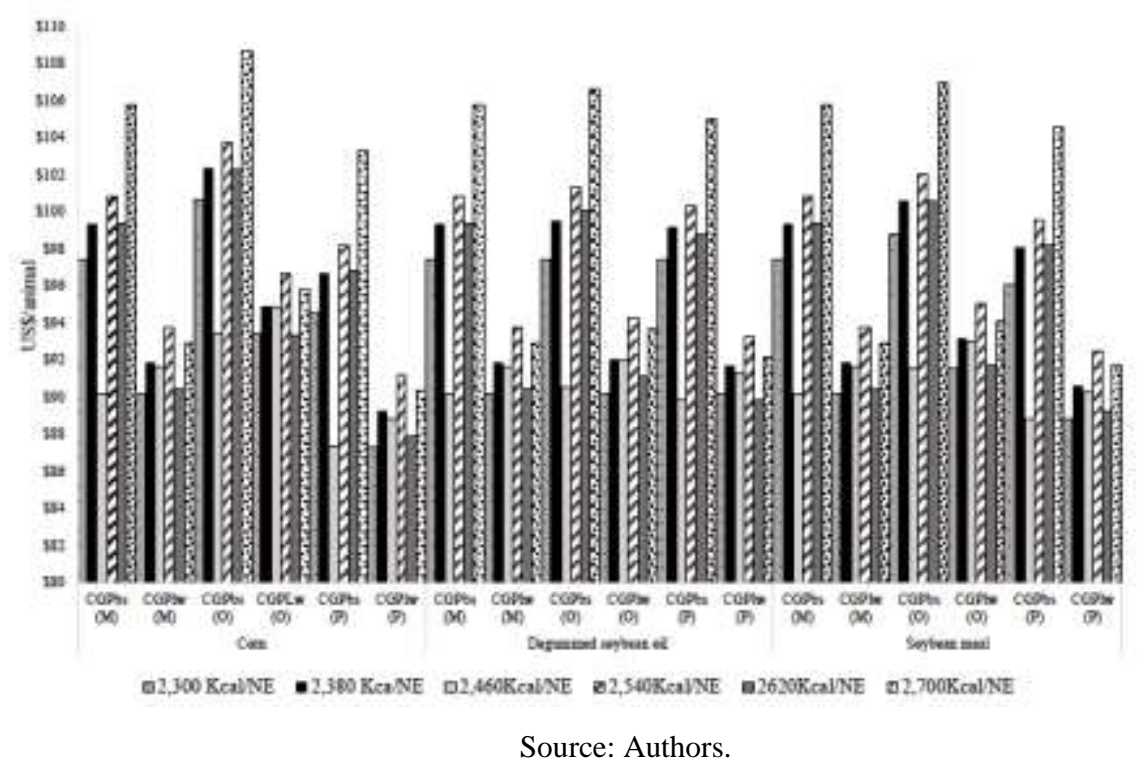

The simulations economics (MOP) carried out on the price of corn, degummed soybean oil and soybean meal of the nutritional plans for gilts are arranged in Figure 2. Price variations of corn in the optimistic scenario combined with increased energy concentration of the diets from 2,460 kcal to 2,700 kcal improved the CGPbs up to $16 \%$ per animal. The CGPlw was higher when using diets with $2,540 \mathrm{kcal}$ of NE.

Similar results were observed for the price of degummed soybean oil and soybean meal (Figure 2), with the highest CGPbs obtained at the level of 2,700 kcal of NE, and for CGPlw at the level of 2,540 kcal of NE. For degummed soybean oil, the increase in the energy concentration generated an efficiency in the CGPbs up to $17 \%$ when comparing the level of 2,700 and 2,460 kcal of NE. While for soybean meal, the increase in CGPbs was $16.85 \%$. Therefore, the increase in energy density led to increased economic gains. These results are related to the revenue generated (Table 2), since higher NE levels provided high revenue (RCbs and RLws). Conversely, the feed cost of the weight gain (FCwg) also increased as the NE increased. However, gilts were more efficient in converting feed into weight gain (Gattás et al., 2012), therefore positive economic gains were observed in diets with 2,700 Kcal of NE. Similar results were observed by Moura et al. (2011), who reported that supplying 2,668 kcal of NE for gilts resulted in higher rates of carcass in bonus system, which is likely to generate more revenue and profit compared to lower NE levels.

The literature demonstrates that the concentration of net energy in diets is positively correlated with weight gain (Wu et al., 2007). Moehn et al. (2013), observed an increase in the final weight of the animals and an improvement in the digestibility of the nutrients of the diet. While, Paiano et al. (2008) found a reduction in feed intake of barrows and gilts of 60 to $90 \mathrm{~kg}$ with increasing levels of NE $(2,410$ and $2,570 \mathrm{kcal} / \mathrm{kg})$ in the diet. Saraiva et al. (2014) found a linear increase in the weight gain of swine fed diets containing 2,666 kcal of NE.

The simulations carried out on the price paid per kilogram of swine for sale (Figure 3) for barrows and gilts that were fed different levels of NE, demonstrated that the intermediate level of $\mathrm{NE}(2,460 \mathrm{kcal} / \mathrm{kg})$ improved profitability, providing an increase of $3.72 \%$ in CGPbs per animal compared to the level of 2,620 kcal of NE for barrows. Whereas the simulations in the commercialization price of females (Figure 3), demonstrated that the use of diets with 2,700 kcal of NE in CGPbs, caused a 
reduction in profitability of up to $16.03 \%$ per animal when NE was 2,460 kcal. The CGPlw was $3.05 \%$ higher with NE elevation in the diets up to $2,700 \mathrm{kcal}$ in relation to the basal level of NE evaluated.

Figure 3 Gross profit when carcasses were sold based on bonus system (CGPbs) and gross profit when sold based solely on live weight $(\mathrm{CGPlw})$ from the analysis scenarios, more probable $(\mathrm{M})$, optimistic $(\mathrm{O})$ and pessimistic $(\mathrm{P})$, on the price paid per kilogram of the swine, applied in nutritional plans of net energy for barrows and gilts.

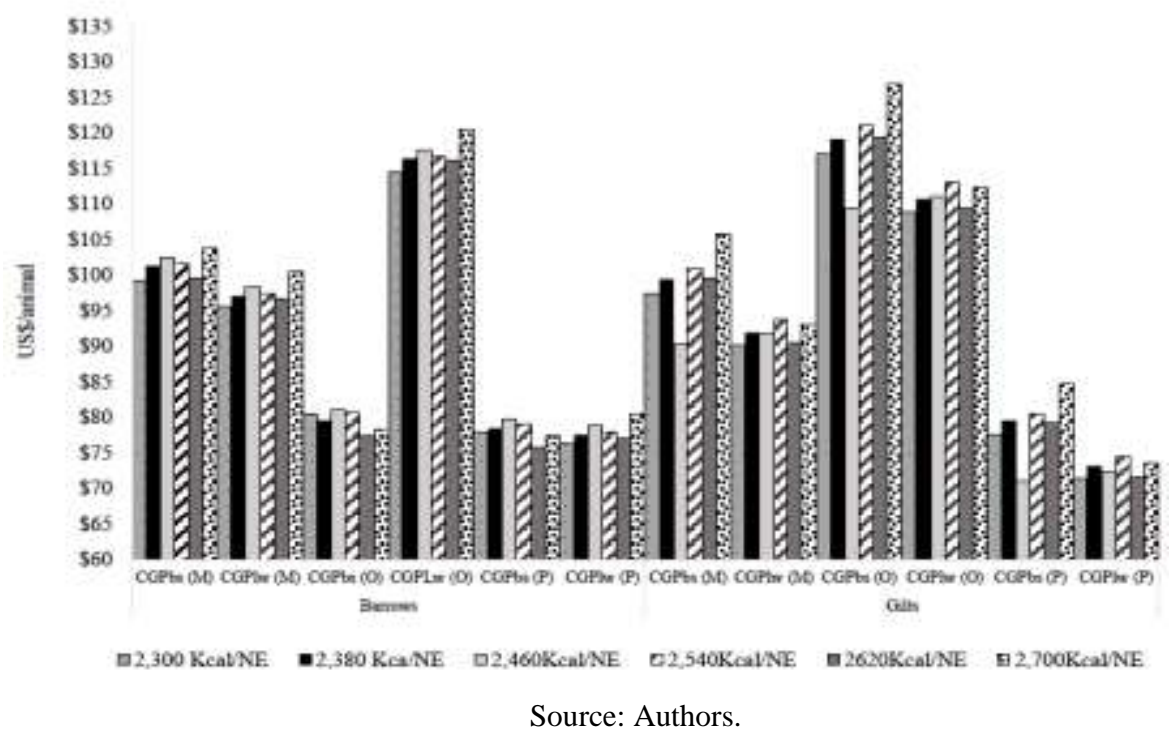

The economic results for the simulations in the price paid per kilogram of swine showed that the intermediate level of NE $(2,460 \mathrm{kcal} / \mathrm{kg})$ increased CGPbs. This is likely related to lower nutritional cost for this level in conjunction with RCbs returns increasing, thus generating better economic gains.

However, the CGPlw presented opposite behavior for these simulations, because the higher level of inclusion of NE $(2,700 \mathrm{kcal} / \mathrm{kg})$ provided the greatest economic gains, which is possibly related to RLws which was higher for this level, even considering higher feed costs (FCwg).

Regarding CGPbs and CGPlw, the highest values in profitability were obtained in the bonus system, which may be associated with carcass quality. The bonus system has a higher value payment in comparison to the payment received for the marketing of animals by live weight (Barbosa et al., 2005).

Overall, profitability was reduced for diets containing 2,300 kcal of NE. This demonstrates that adding a lower energy concentration in the growing and finishing swine diets reduces earnings for the producer. However, further studies should be carried out to verify that the changes in energy concentrations of the diet has an effect on the profitability of the swine farm.

\section{Conclusion}

Raising the NE level of the diet from 2,300 to 2,700 kcal/kg for barrows and gilts during the growing and finishing phases increased profitability, independent of the market condition and the way in which the animals are commercialized. Even with high feed cost, the increase in energy density raised the slaughter weight of animals, and increased revenues generated.

The results of this study demonstrate that, connect the analyzes of technical performance with economic allows the foundation for the maximization of managerial decision-making, as, decide for maximum profit or minimum cost of diets applied to swine production systems. 


\section{Acknowledgments}

The authors are grateful to the Coordenação de Aperfeiçoamento de Pessoal de Nível Superior (CAPES) - Brazil, financial code 001

\section{References}

Ali, B. M.; Berentsen, P. B. M.; Bastiaansen, J. W. M. \& Oude Lansink, A. (2018) A stochastic bio-economic pig farm model to assess the impact of innovations on farm performance. Animal, 12(4), 819-830.

Barbosa, H. C. A.; Vieira, A. A.; Teixeira, Z. S.; Almeida, F. Q. \& Campos, J. F. (2002). Performance of pigs in finishing period fed with different leveis of feed restriction levei and of energy in the diet. Revista Brasileira de Ciências Veterinárias, 9, 147-153.

Barbosa, L.; Lopes, P. S.; Regazzi, A. J.; Guimarães, S. E. F. \& Torres, R. A. (2005). Evaluation of swine carcass traits using principal components. Revista Brasileira de Zootecnia, 34, 2209-2217.

Centro de estudos avançados em economia aplicada - CEPEA (2017). Banco de dados. 2017. https://www.cepea.esalq.usp.br/br

Gattás, G.; Silva, F. C. O.; Barbosa, F. F.; Donzele, J. L. \& Ferreira, A. S. (2012). Digestible lysine inclusion in diets for gilts from 60 to 100 days of age. Arquivo Brasileiro de Medicina Veterinária e Zootecnia, 64, 1317-1324.

Guidoni, A. L. (2000). Melhoria de processos para tipificação e valorização de carcaças suínas no Brasil. Anais da Conferência Internacional Virtual sobre Qualidade de Carne Suína. BR: EMBRAPA.

Gonçalves, L. M. P.; Kiefer, C.; Souza, K. M. R.; Marçal, D. A.; Abreu, R. C.; Silva, A. M. P. S. \& Alencar, A. A. S. Net energy levels for finishing barrows. Ciência Rural, 45, 464-469.

Kil, D. Y.; Kim, B. G. \& Stein, H. H. (2013). Feed energy evaluation for growing pigs. Asian-Australasian Journal of Animal Science, $26,1205-1217$.

Koche, J. C. (2011). Fundamentos de metodologia científica: teoria da ciência e iniciação à pesquisa. Petrópolis: Vozes.

Leite, E. A. M.; Lencastre, J. A. \& Silva, B. D. (2020). Systematic review: learning styles as a strategy for elaboration of courses in the modality of distance education in higher education. Research, Society and Development, 9(3), e172932339.

Marçal, D.; Kiefer, C.; Nascimento, K. M. R. S.; Bonin, M. N.; Corassa, A.; Alencar, S. A. S.; Santos, A. P. \& Rodrigues, G. P. (2018a). Dietary net energy plans for barrows from 25 to $100 \mathrm{~kg}$ body weight. Revista Brasileira de Zootecnia, 47, e20180038.

Marçal, D.; Kiefer, C.; Nascimento, K. M. R. S.; Bonin, M. N.; Corassa, A.; Alencar, S. A. S. \& Silva, J. L. (2018b). Dietary net energy for gilts from 25 to 100 kg body weight. Revista Brasileira de Zootecnia, 47, e2017034.

Mensi, W.; Tiwari, A.; Bouri, E.; Roubaud, D. \& Al-Yahyaee, K. H. (2017). The dependence structure across oil, wheat, and corn: A wavelet-based copula approach using implied volatility indexes. Energy Economics, 66, 122-139.

Moehn, S.; Levesque, C. L. \& Ball, R. O. (2013). Protein intake but not feed intake affects dietary energy for finishing pigs. Journal of Animal Physiology and Animal Nutrition, 97, 197-204.

Moura, M. S.; Kiefer, C.; Silva, C. M.; Nantes, C. L. \& Silva, E. A. (2011). Net energy and ractopamine levels for finishing gilts under thermal comfort. Revista Brasileira de Zootecnia, 40, 1968-1974.

National Research Council - NRC (2012). Nutrient requirements of swine. Washington: NRC.

Paiano, D.; Moreira, I.; Furlan, A. C.; Carvalho, P. L. O. \& Kuroda Júnior, E. N. M. (2008). Digestible threonine:lysine ratios and net energy levels in growing/finishing pigs. Revista Brasileira de Zootecnia, 37, 2147-2156.

Patience, J. F.; Rossoni-Serão, M. C. \& Gutiérrez, N. A. (2015). A review of feed efficiency in swine: biology and application. Journal of Animal Science and Biotechnology, 6(33), 1-9.

Pereira, A. S., Shitsuka, D. M., Parreira, F. J. \& Shitsuka, R. (2018). Metodologia da pesquisa científica [recurso eletrônico]. Santa Maria, BR: UAB/NTE/UFSM.

Rostagno, H. S.; Albino, L. F. T.; Hannas, M. I.; Donzele, J. L. \& Perazoo, F. G. (2011). Tabelas brasileiras para aves e suínos: composição de alimentos e exigências nutricionais. BR: Academic Press.

Rostagno, H. S.; Albino, L. F. T.; Hannas, M. I.; Donzele, J. L. \& Perazoo, F. G. (2017). Tabelas brasileiras para aves e suínos: composição de alimentos e exigências nutricionais. BR: Academic Press. 
Research, Society and Development, v. 10, n. 4, e47310414222, 2021

(CC BY 4.0) | ISSN 2525-3409 | DOI: http://dx.doi.org/10.33448/rsd-v10i4.14222

Roever, L. (2017). Compreendendo os estudos de revisão sistemática. Revista da Sociedade Brasileira de Clínica Médica, 15(2), 127-130.

Saraiva, A.; Donzele, J. L.; Oliveira, R. F. M.; Silva, F. C. O.; Abreu, M. L. T.; Santos, F. A. \& Haese, D. (2014). Net energy for 60 to $120 \mathrm{~kg}$ pigs fed low-crude protein diets. Ciência Rural, 44, 1632-1638.

Weston, J. F. \& Brigham, E. F. (2000). Fundamentos da administração financeira. BR: Makron Books.

Wu, Z.; Li, D.; Ma, Y.; Yu, Y. \& Noblet J. (2007). Evaluation of energy systems in determining the energy cost of gain of growing-finishing pigs fed diets containing different levels of dietary fat. Archives of Animal Nutrition, 61, 1-9. 